\title{
Effects of postgrazing residue on morphogenetic and structural characteristics of Tifton 85 pastures
}

\section{Efeitos de resíduos pós-pastejo sobre características morfogênicas e estruturais de pastos de Tifton 85}

\author{
Wilton Ladeira da Silva ${ }^{1 *}$; Euclides Braga Malheiros ${ }^{2}$; Ricardo Andrade Reis ${ }^{3}$; \\ Américo Garcia da Silva Sobrinho ${ }^{3}$; Ana Cláudia Ruggieri ${ }^{3}$
}

\begin{abstract}
The ideal time to start grazing is when pastures reach $95 \%$ light interception. The use of residual leaf area index (rLAI) to time the interruption of grazing under intermittent grazing has recently been studied in forage species in different climatic conditions in Brazil. However, studies evaluating the formation and development of leaves and tillers through morphogenetic and structural variables in functional rLAI are still lacking for Tifton 85 pastures. Therefore, the objective of this study was to evaluate the effects of varying rLAI in successive grazing cycles on morphogenetic and structural characteristics of Tifton 85 pasture grazed intermittently by sheep. Morphogenetic and structural characteristics were evaluated in three grazing cycles under three rLAI conditions $(0.8,1.6$, and 2.4). The regrowth interval (time taken to return to $95 \%$ light interception) of pastures increased from 21.33 to 29.66 days with decreasing rLAI. The leaf appearance rate increased at a rate of 0.02 leaves tiller ${ }^{-1}$ day $^{-1}$ and the number of live leaves per tiller increased by 0.41 with decreasing rLAI. Phyllochron, leaf elongation rate, final leaf length, leaf senescence rate, and stem elongation rate decreased linearly with decreasing rLAI. The number of live leaves per tiller was lower (7.97) in the third grazing cycle, probably owing to the higher senescence rate observed that same cycle, while the other variables had higher values. The $2.4 \mathrm{rLAI}$ condition promotes excessive stem elongation, reduced leaf appearance, lower number of live leaves per tiller, and increased senescence of leaves, while the 0.8 and $1.6 \mathrm{rLAI}$ conditions promote desirable morphogenetic and structural characteristics, which correlate directly with forage quality. In order to avoid excessive forage losses, grazing must occur preferentially by the end of March, when climatic conditions still support the appropriate development of the plants.
\end{abstract}

Key words: Grazing cycles. Leaves appearance. Light interception. Residual leaf area index. Stem elongation.

\section{Resumo}

O momento de iniciar o pastejo quando os pastos atingem $95 \%$ de interceptação luminosa e de interrupção do pastejo por meio de índices de área foliar residual (IAFr), em situação de pastejo intermitente, recentemente vem sendo estudado em espécies forrageiras em distintas condições climáticas do Brasil, porém, pesquisas avaliando a formação e desenvolvimento de folhas e perfilhos por meio das variáveis morfogênicas e estruturais em função de IAFr são ainda inexistentes em pastos de Tifton 85. Por isso,

\footnotetext{
${ }^{1}$ Dr. em Zootecnia, Universidade Estadual Paulista, UNESP, Campus de Jaboticabal, Jaboticabal, SP, Brasil. E-mail: wiltonladeira@ yahoo.com.br

2 Prof., Departamento de Ciências Exatas, UNESP, Campus de Jaboticabal, Jaboticabal, SP, Brasil. E-mail: euclides@fcav.unesp. br

${ }^{3}$ Profs., Departamento de Zootecnia, UNESP, Campus de Jaboticabal, Jaboticabal, SP, Brasil. Membros do INCT/CA. E-mail: acruggieri@fcav.unesp.br; rareis@fcav.unesp.br; americo@fcav.unesp.br

* Author for correspondence
} 
objetivou-se com este trabalho, avaliar os efeitos de IAFr dos pastos, em ciclos de pastejos sucessivos, sobre as características morfogênicas e estruturais de Tifton 85 pastejados de maneira intermitente por ovinos. Características morfogênicas e estruturais dos pastos foram avaliadas em três ciclos de pastejo em função de três $\operatorname{IAFr}(0,8 ; 1,6$ e 2,4). O intervalo de rebrotação dos pastos aumentou de 21,33 para 29,66 dias com a diminuição do IAFr. A taxa de aparecimento de folhas aumentou 0,02 folhas perfilho ${ }^{-1} \mathrm{dia}^{-1} \mathrm{e}$ o número de folhas vivas por perfilho aumentou $0,41 \mathrm{com}$ a diminuição do IAFr. Filocrono, taxa de alongamento de folhas, comprimento final de folha, taxa de senescência foliar e taxa de alongamento do colmo decresceram linearmente com a diminuição do IAFr dos pastos. Somente o número de folhas vivas por perfilho foi menor $(7,97)$ no terceiro ciclo de pastejo, provavelmente pela maior taxa de senescência observada naquele mesmo ciclo enquanto as demais variáveis apresentaram maiores valores. O IAFr 2,4 promove alongamento excessivo de colmos, aparecimento reduzido de folhas, menor número de folhas vivas por perfilho e maior senescência de folhas, enquanto os IAFr 0,8 e 1,6 promovem características morfogênicas e estruturais desejáveis, as quais se correlacionam diretamente á qualidade da forragem. Para evitar perdas excessivas de forragem, o pastejo deve ocorrer, preferencialmente, até final do mês de março, onde as condições climáticas ainda favorecem o adequado desenvolvimento das plantas.

Palavras-chave: Alongamento do colmo. Aparecimento de folhas. Ciclos de pastejo. Índice de área foliar residual. Interceptação de luz.

\section{Introduction}

Animal production in pastures requires effective management. For rotational stocking, timely and accurate information is needed to determine the timing of the start and interruption of grazing in a given pasture to avoid major losses in production.

Measurement of light interception (LI) by the sward in order to determine the best time to start grazing has been used in experimental conditions in tropical regions, mainly in Brazil, because several scientific results showed a correlation between LI with forage production and nutritive value (CUNHA et al., 2010; DIFANTE et al., 2010; GALZERANO et al., 2013; SOUSA et al., 2013; SILVA et al., 2013). The best point to begin animal grazing is considered to be when the sward is achieving an average of $95 \%$ light interception. Regarding the interruption of animal grazing, the residual leaf area index (rLAI) technique was and is being used in research in different forages and conditions in Brazil (CUTRIM JÚNIOR, 2010, 2011; SILVA et al., 2013; GALZERANO et al., 2013), though less commonly than other techniques such as measurement of postgrazing heights, herbage allowance, or fixed days.

The study of rLAI allows a better understanding of the relationship between light interception and dry matter accumulation in plants (PARSONS;
CHAPMAN, 1998), because it is influenced by the formation and development of leaves, which are essential for plant growth. However, studies evaluating the formation and development of leaves through the morphogenetic and structural variables due to rLAI in Tifton 85 pastures are still lacking. Thus, investigation of those morphogenetic characteristics of the pastures that are directly related to changes in the structural characteristics under grazing would be useful to assist in the identification and strategic planning of grazing management in order to achieve longevity, productivity, and sustainability of the pasture ecosystem. Thus, the aim of the present study was to evaluate the effects of varying rLAI in successive grazing cycles on the morphogenetic and structural characteristics of Tifton 85 grazed intermittently by sheep.

\section{Materials and Methods}

The study was conducted on the experimental Tifton 85 pastures (Cynodon spp.) formed 10 years ago in UNESP, Sao Paulo State University, Jaboticabal, SP, Brazil (21 $\left.1^{\circ} 15^{\prime} \mathrm{S}, 48^{\circ} 18^{\prime} \mathrm{W}\right)$, from December 2008 to April 2009. The experimental site is $595 \mathrm{~m}$ above sea level, characterized by a gently rolling topography with Oxisol and clayey soil type (EMBRAPA, 2006). The 0 to $20-\mathrm{cm}$ layer has the 
following chemical characteristics: $\mathrm{pH} \mathrm{CaCl}_{2}=$ 4.95; P (ion- Exchange resin extraction method) $=$ $14 \mathrm{mg} \mathrm{dm}^{-3} ; \mathrm{K}^{+}=3.6$ mmolc dm$^{-3}$; organic matter $=32.5 \mathrm{~g} \mathrm{dm}^{-3} ; \mathrm{H}^{+}+\mathrm{Al}^{+3}=40.0$ mmolc dm${ }^{-3} ; \mathrm{Ca}^{2+}$ $=31.0$ mmolc dm $\mathrm{mg}^{-3} \mathrm{Mg}^{2+}=13.0$ mmolc dm $\mathrm{dm}^{-3}$ and saturation base $=59.0 \%$.
The local climate is classified by Köppen as Aw, tropical humid with rainy summers and dry winters. The average temperature during the experimental period ranged from 19.0 to $25.0^{\circ} \mathrm{C}$ and the average monthly rainfall from 70.8 to $278.9 \mathrm{~mm}$ (Figure 1). From the end of March and during April, both temperatures and rainfall decreases sharply.

Figure 1. Average rainfall $(\mathrm{mm})$ and minimum (Tmin), average (Tav) and maximum (Tmax) temperatures $\left({ }^{\circ} \mathrm{C}\right)$ during the experimental period.

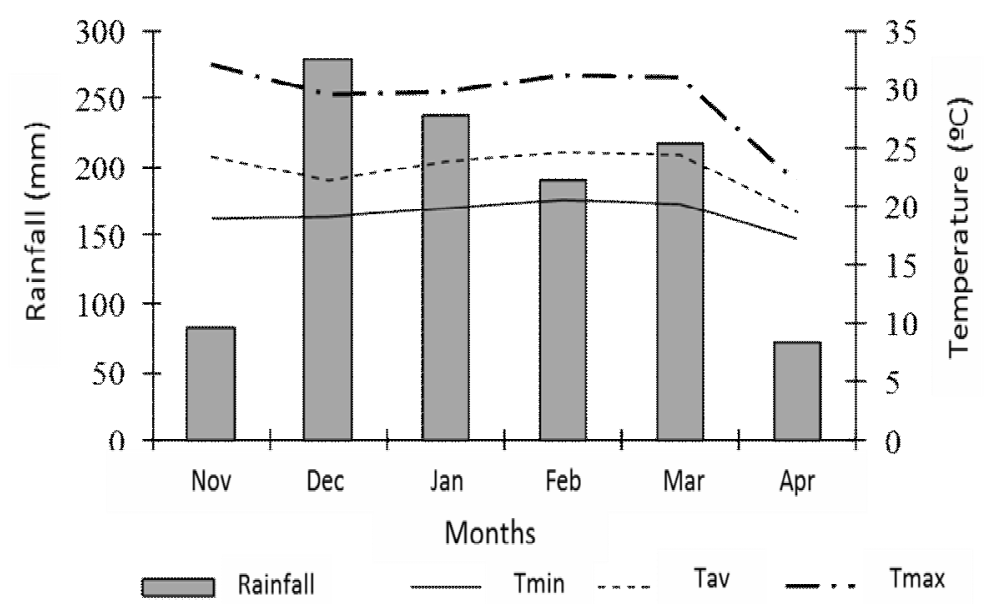

Fonte: Compiled from data obtained in the Agrometeorology Station of UNESP, Jaboticabal.

The treatments consisted of three post-grazing residues defined by the rLAI of $0.8,1.6$, and 2.4 , evaluated in a randomized block design with seven blocks, totaling 21 experimental units or pastures. The pasture areas were 135, 175, and $235 \mathrm{~m}^{2}$ with rLAIs of $0.8,1.6$, and 2.4 respectively. Ile de France and Santa Inês sheep, of $40 \mathrm{~kg}$ average live weight, were used in rotational stocking with three days of occupation.

The rLAI was measured daily on each pasture during the grazing period. When the rLAI was achieved, the animals were transferred to the pasture where the 95\% light interception $\left(\mathrm{LI}_{95 \%}\right)$ had been reached during the resting period.

The light interception (LI) in the pasture was monitored from the animal removal throughout the resting period until it reached $\mathrm{LI}_{95 \%}$. LI readings were performed weekly until the value was close to $93 \%$, and then, daily until the $\mathrm{LI}_{95 \%}$ target was reached. LI and rLAI readings were performed between $11 \mathrm{~h} 00$ and $13 \mathrm{~h} 00$ using the AccuPAR LP80 ceptometer following the instruction manual (Decagon Devices, Pullman, WA). For both LI and rLAI, twenty random readings were performed per pasture. The Accupar system measured the incident and spread transmitted light, beam fraction, zenith angle, and LAI. Canopy LI was calculated by dividing the transmitted by the incident light and multiplied by 100 , and then subtracting the result from 100 (AGUIAR et al., 2014).

In November and December 2008, the treatments were installed and in January 2009, grazing cycles and sampling were started. Samples were taken until April 2009, when three grazing cycles had been completed in all treatments. One grazing cycle is the grazing period of the animals added to 
the resting period (RP) of the pasture. The RP was defined as the time (days) that pastures after the third grazing day take to intercept $\mathrm{IL}_{95 \%}$ again. At the end of each grazing cycle all pastures received $50 \mathrm{~kg} \mathrm{~N} \mathrm{ha}^{-1}$ through the application of 20:05:20 (N: $\mathrm{P}_{2} \mathrm{O}_{5}: \mathrm{K}_{2} \mathrm{O}$ ), which totaled $150 \mathrm{~kg} \mathrm{~N} \mathrm{ha}^{-1}$ at the end of the experimental period.

Evaluations of morphogenetic and structural characteristics were made in three tillers per pasture twice a week throughout the resting period, totaling 21 tillers evaluated per treatment in each grazing cycle. After each grazing period, a new group of three tillers, always selected from those of average height for the pasture, was marked. This procedure was repeated until the end of the experiment.

For the evaluations, graduated rulers in centimeters were used. Leaf blade length $(\mathrm{cm})$, stem length (stem + sheath), leaf senescence $(\mathrm{cm})$ were recorded and the number of emerged leaves on each tillers were counted. The leaves were classified as expanded when a visible ligule was present and as dead when the leaf blade was 50\% or more compromised by senescence. With these data, the following variables were quantified: (i) leaf appearance rate (LAR, leaf tiller ${ }^{-1}$ day $^{-1}$ ): relationship between the number of emerged leaves per tiller and number of evaluation period; (ii) Phyllochron (PHYL, days leaf ${ }^{-1}$ ): inverse of leaf appearance rate; (iii) leaf elongation rate (LER, cm tiller ${ }^{-1}$ day $\left.^{-1}\right)$ : relationship between difference in the leaf blade length $(\mathrm{cm})$ at end and at beginning and the number of evaluation period; (iv) stem elongation rate $\left(\mathrm{SER}, \mathrm{cm}\right.$ tiller $^{-1}$ day $\left.^{-1}\right)$ : relationship between stem length difference at end and at beginning and the number of evaluation period; (v) final leaf blade length (FLL, cm): average leaf blade length of all expanded leaves on a tiller, measured the leaf apex to the ligule; (vi) number of live leaves per tiller (NLL): average number of leaves growing and expanded per tiller during the evaluation period, except senescent leaves that had more than $50 \%$ of the leaf blade length affected; (vii) leaf lifespan (LLS, days) is the mean time, in days, between the leaf appearance and the leaf death; (viii) leaf senescence rate (LSR cm tiller ${ }^{-1}$ day $^{-1}$ ): relationship between the sum of the leaf senescent length present at the tiller and the number of days of the evaluation period.

Statistical analyses were performed considering the effects of rLAI and GC as fixed, and the block effect as random. We used the MIXED procedure of SAS software, version 9.2 (SAS, 2008). The means were compared by orthogonal contrasts at $5 \%$ probability, with subsequent adjustment of the linear regression equations.

\section{Results and Discussion}

No significant interaction ( $\mathrm{P} \geq 0.05)$ between $r L A I$ $x$ GC on length of resting period (RP) (Table 1). The $\mathrm{RP}$ increased linearly $(\mathrm{P}<0.05)$ was observed with decreasing rLAI and over the GC.

Table 1. Resting period (days) of Tifton 85 pastures managed under three residual leaf area index (rLAI) during three grazing cycles (GC).

\begin{tabular}{cccccc}
\hline & rLAI 2,4 & rLAI 1,6 & rLAI 0,8 & Average & p $^{(1)}$ cont. \\
\hline $\mathrm{GC}_{1}$ & 20.0 & 24.0 & 29.0 & 24.33 & \\
$\mathrm{GC}_{2}$ & 22.0 & 25.0 & 29.0 & 25.33 & \\
$\mathrm{GC}_{3}$ & 22.0 & 25.0 & 31.0 & 26.00 & \\
Average & 21.33 & 24.66 & 29.66 & & $\mathrm{~L}(<0.0001)$ \\
$\mathrm{p}^{(1)}$ cont. & & & & $\mathrm{L}(<0.0001)$ & \\
\hline
\end{tabular}

(1) Probability associated with $\mathrm{F}$ test for contrasts; $\mathrm{L}=$ linear effect. 
The RP increase with rLAI decrease is likely to be due to increased grazing intensity, which reduces the proportion of leaves remaining after grazing. Thus, with a smaller leaf area remaining, the photosynthetic rate is reduced and the use of organic reserves increases, which means more time is required for canopy recovery and return to $95 \%$ light interception.

Tillering in grasses probably contributed to the lower resting period in $\mathrm{GC}_{1}$, because during this cycle the environmental conditions such as precipitation and temperature were more favorable (Figure 1) to tillering than the conditions observed in $\mathrm{GC}_{3}$, as shown by Silva et al. (2013). These authors observed a higher tillering appearance rate in Tifton 85 pastures in $\mathrm{GC}_{1}(68.1 \%)$ compared to $\mathrm{GC}_{2}(38.9 \%)$ and $\mathrm{GC}_{3}(34.6 \%)$ in the same experimental area and under the same management conditions. Thus, greater tillering capacity probably meant the target of $\mathrm{LI}_{95 \%}$ was achieved in a shorter time interval.

There was not a significant interaction $(\mathrm{P} \geq 0.05)$ between rLAI x GC on morphogenetic and structural variables of pastures. With the exception of LLS other variables were affected linearly $(\mathrm{P}<0.05)$ by rLAI (Table 2).

Table 2. Leaf appearance rate (LAR), phyllochron (PHYL), leaf elongation rate (LER), final leaf blade length (FLL), leaf senescence rate (LSR), leaf lifespan (LLS), number of live leaves per tiller (NLL) and stem elongation rate (SER) of Tifton 85 pastures in rotational stocking by three residual leaf area index (rLAI).

\begin{tabular}{|c|c|c|c|c|c|c|c|}
\hline \multicolumn{3}{|c|}{ Treatments } & \multicolumn{2}{|c|}{$P$ value } & \multicolumn{2}{|c|}{ Estimates } & \multirow[b]{2}{*}{$\mathrm{R}^{2}$} \\
\hline rLAI 2.4 & rLAI 1.6 & rLAI 0.8 & $\mathrm{~L}$ & Q & $\mathrm{b}_{0}$ & $\mathrm{~b}_{1}$ & \\
\hline & LAR (leaf tiller ${ }^{-1}$ day $^{-1}$ ) & & & & & & \\
\hline $0.29(0.01)$ & $0.31(0.01)$ & $0.34(0.01)$ & 0.0173 & 0.7331 & 0.26 & 0.02 & 0.99 \\
\hline & PHYL (days leaf ${ }^{-1}$ ) & & & & & & \\
\hline $3.65(0.11)$ & $3.35(0.14)$ & $3.13(0.10)$ & 0.0130 & 0.7885 & 3.90 & -0.26 & 0.99 \\
\hline & LER $\left(\mathrm{cm}\right.$ tiller ${ }^{-1}$ day $\left.^{-1}\right)$ & & & & & & \\
\hline $5.11(0.13)$ & $4.88(0.27)$ & $4.27(0.17)$ & $<0.0001$ & $<0.0009$ & 5.59 & -0.42 & 0.93 \\
\hline & FLL (cm) & & & & & & \\
\hline $10.84(0.29)$ & $10.12(0.41)$ & $9.64(0.42)$ & 0.0020 & 0.6700 & 11.40 & -0.60 & 0.99 \\
\hline & LSR (cm tiller ${ }^{-1}$ day $\left.^{-1}\right)$ & & & & & & \\
\hline $0.46(0.05)$ & $0.41(0.05)$ & $0.33(0.04)$ & 0.0109 & 0.5973 & 0.53 & -0.07 & 0.97 \\
\hline & LLS (days) & & & & & & \\
\hline $28.71(0.83)$ & $28.56(0.87)$ & $27.56(0.74)$ & 0.1948 & 0.5646 & - & - & - \\
\hline & NLL & & & & & & \\
\hline $7.96(0.15)$ & $8.31(0.24)$ & $8.79(0.26)$ & 0.0480 & 0.8567 & 7.53 & 0.41 & 0.91 \\
\hline & SER (cm tiller ${ }^{-1}$ day $\left.^{-1}\right)$ & & & & & & \\
\hline $0.67(0.03)$ & $0.62(0.04)$ & $0.51(0.03)$ & 0.0070 & 0.5334 & 0.76 & -0.08 & 0.96 \\
\hline
\end{tabular}

* Standard error of the mean in parentheses; L and Q linear and quadratic effect for rLAI respectively; $\mathrm{R}^{2}$ : coefficient of determination (Sum of square model / Sum of square treatment). 
The leaf appearance rate (LAR) increased linearly by 0.02 leaves tiller ${ }^{-1}$ day $^{-1}$ with decreasing rLAI. This effect occurred because in the plant growth process the LAR tends to decrease with increasing sheath length. This results in greater distance to be covered by leaves before exposure (LEMAIRE; CHAPMAN, 1996). Likewise, Pereira et al. (2011) observed increased LAR of 0.0667 and 0.00292 leaves tiller ${ }^{-1}$ day $^{-1}$ for every reduction of one centimeter in plant height in Tifton 85 plants in two experimental years.

Phyllochron (PHYL), which corresponds to the period between the appearance of two consecutive leaves in the same tiller, decreased linearly $(\mathrm{P}<0.05)$ with decreasing rLAI. Phyllochron follows an inverse logic to LAR, because increasing grazing intensity or cutting tends to reduce the time between the appearance of two successive leaves, probably due to the need of the plant to restore the photosynthetic apparatus quickly after the intensive grazing. Phyllochron values from 1.44 to 4.10 days leaf ${ }^{-1}$ and from 1.16 to 3.89 days leaf ${ }^{-1}$ were observed by Oliveira et al. (2000) and by Pereira et al. (2011) in Tifton 85 plants under cuts, respectively. The cuts were determined by regrowth days and cutting heights.

The leaf elongation rate (LER) decreased (0.42 $\mathrm{cm}$ tiller $^{-1}$ day $^{-1}$ on average) with decreasing rLAI. The highest rate observed in greater rLAI can be justified by stem elongation. Short stems favor a faster leaf emergence, resulting in a lower LER. The opposite occurs with larger stems, which leaves take longer to emerge from, resulting in higher LER. An example of a positive linear response between LER and the increased pasture height was verified by Pontes et al. (2003). These authors worked with annual ryegrass (Lolium multiflorum Lam.) managed in different heights and also observed higher LER in pastures managed higher.

Final leaf blade length (FLL) decreased from 10.84 to $9.64 \mathrm{~cm}$ with decreasing rLAI. The FLL is a plastic characteristic of the plant that responds to grazing intensity imposed on pastures and it is considered a morphological plant strategy to be less affected in grazing (LEMAIRE; CHAPMAN, 1996). According to Grant et al. (1981), the greater FLL values are associated with greater defoliation heights owing to the large sheath length, which is directly related to the SER. The leaf sheath size is greater at pastures kept higher than in pastures kept lower, which increases the distance that the leaf blade will travel from the apical meristem to the emergence, resulting in increased length of the expanded leaf.

Leaf senescence rate (LSR) decreased on average $0.07 \mathrm{~cm}_{\text {tiller }}^{-1}$ day $^{-1}$ with decreasing rLAI. This LSR was on average $28 \%$ and $17 \%$ higher in pastures under $2.4 \mathrm{rLAI}$ and $1.6 \mathrm{rLAI}$, respectively, compared to $0.8 \mathrm{rLAI}$. This senescence process, according to Wilhelm and Mcmaster (1995), is progressively accentuated with increasing sward LAI, caused by the shading of the lower layer of the canopy by the higher layer. Knowing that leaf senescence is directly linked to forage losses and reduction in nutritional value (PEREIRA et al., 2011), animals grazing under conditions imposed by 0.8 rLAI, based only on this variable, would be according to the management for quantity defined by Paulino et al. (2004).

Leaf lifespan (LLS) was not affected $(\mathrm{P} \geq 0.05)$ by rLAI and was approximately 28 days in all treatments. An analysis of how LSR interacts with PHYL can explain this result, because increasing PHYL results in increasing LLS, and increasing LSR favors decreasing LLS. As the greater rLAI provided the highest LSR and PHYL values and the lower rLAI provided the lowest LSR and PHYL values, it is likely that this association tended to maintain the constant LLS between treatments.

Number of live leaves per tiller (NLL), as a variable inversely related to LSR, increased linearly $(\mathrm{P}<0.05)$ with decreasing rLAI, while the LSR decreased with decreasing rLAI. Probably the greater rLAI produced more senescent leaves in the 
canopy base and provided a higher percentage of dead leaves, which provided lower NLL per tiller, and associated with the fact that these pastures managed with greater rLAI had presented the lowest LAR values. Another explanation is based on resting period of pastures, where the greater range (29.6 days) in the pastures managed with 0.8 rLAI (Table 1), resulted in the greater number of emerged leaves per tiller, and so, may have contributed to the greater NLL (8.79).

The stem elongation rate (SER) decreased linearly by $0.08 \mathrm{~cm}^{\text {tiller-1 }}$ day $^{-1}$ with decreasing rLAI. The higher stem elongation in higher rLAI can be attributed to the greater pasture height derived from lower grazing intensity, as shown by Silva et al. (2013). The greater pasture height managed with higher rLAI can be assumed to have led to the mutual shading of tillers and intense competition for light in the canopy, which favored the stem elongation to capture light in the upper canopy layers. In Tifton 85 pastures subjected to rotational stocking, strategies should be prioritized that reduce excessive stem elongation as this increases the rate of plants lodging which results in lower grazing efficiency by animals.

Table 3 shows the morphogenetic and structural characteristics by the grazing cycles. The LER, FLL, LSR, LLS and SER increased linearly $(\mathrm{P}<0.05)$ over the GC, whereas NLL decreased.

Table 3. Leaf appearance rate (LAR), phyllochron (PHYL), leaf elongation rate (LER), final leaf blade length (FLL), leaf senescence rate (LSR), leaf lifespan (LLS), number of live leaves per tiller (NLL) and stem elongation rate (SER) of Tifton 85 pastures in rotational stocking by three grazing cycles.

\begin{tabular}{|c|c|c|c|c|c|c|c|}
\hline & Grazing cycle (GC) & & & & Est & & \\
\hline $1(\mathrm{Jan} / \mathrm{Feb})$ & $\begin{array}{c}2(\mathrm{Feb} / \mathrm{Mar}) \\
\text { LAR (leaf tiller-1 } \text { day }^{-1} \text { ) }\end{array}$ & 3 (Mar/Apr) & $\mathrm{L}$ & Q & $\mathrm{b}_{0}$ & $\mathrm{~b}_{1}$ & $\mathrm{R}^{2}$ \\
\hline $0.30(0.01)$ & $\begin{array}{c}0.32(0.01) \\
\text { PHYL }\left(\text { days leaf }{ }^{-1}\right)\end{array}$ & $0.31(0.01)$ & 0.2585 & 0.1114 & - & - & - \\
\hline $3.24(0.12)$ & $\begin{array}{c}3.18(0.09) \\
\text { LER }\left(\mathrm{cm} \text { tiller }^{-1} \text { day }^{-1}\right)\end{array}$ & $3.30(0.15)$ & 0.2399 & 0.1156 & - & - & - \\
\hline $4.25(0.19)$ & $\begin{array}{l}4.87(0.16) \\
\text { FLL }(\mathrm{cm})\end{array}$ & $5.04(0.25)$ & 0.0343 & 0.6292 & 4.15 & 0.50 & 0.93 \\
\hline $9.95(0.42)$ & $\begin{array}{c}9.51(0.35) \\
\text { LSR }\left(\mathrm{cm} \text { tiller }{ }^{-1} \text { day }^{-1}\right)\end{array}$ & $11.15(0.31)$ & 0.0017 & 0.8007 & 8.99 & 0.60 & 0.99 \\
\hline $0.35(0.04)$ & $\begin{array}{l}0.34(0.04) \\
\text { LLS (days) }\end{array}$ & $0.50(0.05)$ & 0.0092 & 0.2137 & 0.25 & 0.07 & 0.69 \\
\hline $25.69(0.78)$ & $\begin{array}{l}27.86(0.64) \\
\quad \text { NLL }\end{array}$ & $29.28(0.95)$ & 0.0035 & 0.8162 & 27.48 & 1.41 & 0.94 \\
\hline $8.73(0.24)$ & $\begin{array}{c}8.35(0.19) \\
\text { SER }\left(\mathrm{cm} \text { tiller }{ }^{-1} \text { day }^{-1}\right)\end{array}$ & $7.97(0.21)$ & 0.0325 & 0.8471 & 10.34 & -0.25 & 0.87 \\
\hline $0.54(0.04)$ & $0.57(0.03)$ & $0.69(0.04)$ & 0.0080 & 0.1524 & 0.45 & 0.07 & 0.88 \\
\hline
\end{tabular}

* Standard error of the mean in parentheses; L and Q linear and quadratic effect for grazing cycles respectively; $\mathrm{R}^{2}$ : coefficient of determination (Sum of square model / Sum of square treatment).

Despite the previously discussed inverse relationship between the LAR and SER, the LAR was not influenced by $\mathrm{GC}(\mathrm{P} \geq 0.05)$ and had an average value of 0.31 leaves tiller $^{-1}$ day $^{-1}$, while the SER increased linearly with average 0.07 cm tiller ${ }^{-1}$ day $^{-1}$ over the GC. It is known that the trophic resources provided by the environment, such as water and temperature, among others, alter the morphogenetic and structural characteristics of pastures (SILVA; NASCIMENTO JÚNIOR, 2007). 
Lower average temperatures and lower rainfall as observed during $\mathrm{GC}_{3}$ (Figure 1) are some factors that may have contributed to the lower rate of plant growth, beginning the intense process of light competition that intensifies the SER and LSR. In fact, during $\mathrm{GC}_{3}$ the LSR was higher $(0.50 \mathrm{~cm}$ tiller $^{-1}$ day $^{-1}$ ) compared to previous GC.

Phyllochron, inversely related to LAR, which remained constant over the grazing cycles was not affected ( $\mathrm{P} \geq 0.05$ ), ranging from 3.18 to 3.30 days leaf $^{-1}$. These values are close to those observed by Pereira et al. (2011) who recorded phyllochron values of Tifton 85 close to 3 days leaf $^{-1}$ with fertilization of $66 \mathrm{~kg} \mathrm{~N} \mathrm{ha}^{-1}$ during the rainy season.

Leaf elongation rate (LER) increased on average $0.50 \mathrm{~cm}$ tiller $^{-1}$ day $^{-1}$ over the GC. The LER followed the same pattern response of SER in relation to GC, as greater stem elongation means new leaves must grow longer before emergence The increase in LER also explains the linear increase $(\mathrm{P}<0.05)$ in FLL over the grazing cycles once these two variables are correlated directly.

Leaf senescence rate (LSR) increased on average $0.07 \mathrm{~cm}$ tiller $^{-1}$ day $^{-1}$ over the grazing cycles. The LSR values in $\mathrm{GC}_{1}$ and $\mathrm{GC}_{2}$ are below those observed by Pereira et al. (2011) in the same species studied in the months from December to March at different cutting heights and nitrogen fertilization. These authors observed LSR values ranging from $0.56 \mathrm{~cm} \mathrm{tiller}^{-1}$ day $^{-1}$ in the first year of study and $0.51 \mathrm{~cm}^{\text {tiller }}{ }^{-1}$ day $^{-1}$ in the second year with fertilization equivalent to $50 \mathrm{~kg} \mathrm{~N} \mathrm{ha}{ }^{-1}$. As described previously, the climatic conditions observed during the GC may have favored the increase in LSR during $\mathrm{GC}_{3}$, due to increased competition for light in this grazing cycle, when the average temperature and the precipitation were lower compared to the two previous grazing cycles (Figure 1). Knowing that LSR is one of the variables that is associated with forage losses and nutritive value reduction, a system could be developed to time the end of the fattening period of animals on pastures for the end of March to avoid these forage losses and therefore to offer the animals forage in greater quantity and better quality.

Leaf lifespan (LLS) increased on average 1.41 days over the grazing cycles. Although LLS is conditioned by genetic parameters (HODGSON, 1990), it can be modified by environmental conditions. In situations where plant growth is limited, for example, in periods of low rainfall as in $\mathrm{GC}_{3}$ or in the dry season, the plants adopt survival strategies such as increasing nutrient recycling and retaining living tissues for longer.

Number of live leaves per tiller (NLL) ranged from 7.97 to 8.73 leaves tiller ${ }^{-1}$ over the grazing cycles. The observed values were similar to those observed by other authors who also evaluated the NLL in Tifton 85, for example Pereira et al. (2011) who observed approximately 9 leaves tiller $^{-1}$, and Oliveira et al. (2000) who observed values between 8.2 to 9.5 leaves tiller $^{-1}$. It is known that the number of living leaves of each genotype is relatively constant, i.e., in the same tiller while there is a senescent leaf, another emerges. But this only occurs when the tiller is not in early growth or vegetative growth (HODGSON, 1990). As with LLS, both the genetic characteristics of the plant and environmental factors affect NLL (SILVA et al., 2009). During $\mathrm{GC}_{3}$ the increased LSR may have contributed to the lower NLL observed.

Stem elongation rate (SER) increased on average $0.07 \mathrm{~cm}$ tiller ${ }^{-1}$ day $^{-1}$ over the grazing cycles, because there was an increase in the length of the RP needed over the grazing cycles (Table 1). Thus, increasing $\mathrm{RP}$, pastures had more time to continue the stem elongation process. Another possibility was that in $\mathrm{GC}_{3}$ (between the months of March and April) greater competition in light interception occurred between tillers, as during those months close to the dry season, the intensity and quality of light were possibly lower. 


\section{Conclusion}

In Tifton 85 pastures with sheep in rotational stocking, an rLAI of 2.4 favors excessive stem elongation, reduced leaf appearance, lower leaf lifespan per tiller, and increased senescence of leaves. Conversely, pastures managed under lower stubble as 0.8 and 1.6 rLAI have desirable morphogenetic and structural characteristics, such as lower rates of senescence of leaves and lower stem elongation, which relate directly to forage quality. To avoid excessive forage losses, grazing should preferably occur only until the end of March, when the climatic conditions in central Brazil still favor good plant development.

\section{References}

AGUIAR, A. D.; VENDRAMINI, J. M. B.; ARTHINGTON, J. D; SOLLENBERGER, L. E.; SANCHEZ, J. M. D.; SILVA, W. L.; VALENTE, A. L. S.; SALVO, P. Stocking rate effects on Jiggs bermudagrass pastures grazed by heifers receiving supplementation. Crop Science, Madison, v. 54, n. 6, p. 2872-2879, 2014.

CUNHA, B. A. L.; NASCIMENTO JÚNIOR, D.; SILVEIRA, M.C. T.; MONTAGNER, D. B.; EUCLIDES, V. P. B.; SILVA, S. C. da; SBRISSIA, A. F.; RODRIGUES, C. S.; SOUSA, M. L.; PENA, K. S.; VILELA, H. H.; SILVA, W. L. Effects of two post-grazing heights on morphogenic and structural characteristics of guinea grass under rotational grazing. Tropical Grasslands, Queensland, v. 44, n. 4, p. 253-259, 2010.

CUTRIM JÚNIOR, J. A. A.; CÂNDIDO, M. J. D.; VALENTE, B. S. M.; CARNEIRO, M. S. S.; CARNEIRO, H. A. V. Características estruturais do dossel de capim-tanzânia submetido a três frequências de desfolhação e dois resíduos pós-pastejo. Revista Brasileira de Zootecnia, Viçosa, MG, v. 40, n. 3, p. 489497, 2011.

CUTRIM JÚNIOR, J. A. A.; CÂNDIDO, M. J. D.; VALENTE, B. S. M.; CARNEIRO, M. S. S.; CARNEIRO, H. A. V.; CIDRÃO, P. M. L. Fluxo de biomassa em capim-tanzânia sob três frequências de desfolhação e dois resíduos pós-pastejo. Revista Brasileira de Saúde e Produção Animal, Salvador, v. 11, n. 3, p. 618-629, 2010.

DIFANTE, G. S.; EUCLIDES, V. P. B.; NASCIMENTO JÚNIOR, D.; SILVA, S. C. da; BARBOSA, R. A.; TORRES JÚNIOR, R. A. A. Desempenho e conversão alimentar de novilhos de corte em capim-tanzânia submetido a duas intensidades de pastejo sob lotação rotativa. Revista Brasileira de Zootecnia, Viçosa, MG, v. 39, n. 1, p. 33-41, 2010.

EMPRESA BRASILEIRA DE PESQUISA AGROPECUÁRIA - EMBRAPA. Sistema brasileiro de classificação de solos. Brasília: EMBRAPA, 2006. 306 p.

GALZERANO, L.; MALHEIROS, E. B.; RAPOSO, E.; MORGADO, E. S.; RUGGIERI, A. C. Características morfogênicas e estruturais do capim-xaraés submetido a intesidades de pastejo. Semina: Ciências Agrárias, Londrina, v. 34, n. 4, p. 1879-1890, 2013.

GRANT, S. A.; BARTHRAM, G. T.; TORVEL, L. Components of regrowth in grazed and cut Lolium perenne swards. Grass and Forage Science, Oxford, v. 36, n. 3, p. 155-168, 1981.

HODGSON, J. Grazing management: science into practice. New York: John Wiley; Longman Scientific and Technical, 1990. 203 p.

LEMAIRE, G.; CHAPMAN, D. Tissue flows in grazed plants communities. In: HODGSON, J.; ILLIUS, A. $\mathrm{W}$. The ecology and management of grazing systems. London: CAB International, 1996. cap. 1, p. 3-36.

OLIVEIRA, M. A.; PEREIRA, O. G.; HUAMAN, C. A. M.; GARCIA, R.; GOMIDE, J. A.; CECON, P. R.; SILVEIRA, P. R. Características morfogênicas e estruturais do Capim-Bermuda Tifton 85 (Cynodon spp.) em diferentes idades de rebrota. Revista Brasileira de Zootecnia, Viçosa, MG, v. 29, n. 6, p. 1939-1948, 2000.

PARSONS, A. J.; CHAPMAN, D. J. The principles of pasture and utilization. In: HOPKINS, A. Grass: its production \& utilization. Okehampton: British Grassland Society, 1998. p. 31-80.

PAULINO, M. F.; FIGUEIREDO, D. M.; MORAES, E. H. B. K.; PORTO, M. O.; SALES, M. F. L.; ACEDO, T. S.; VILLELA, S. D. J.; VALADARES FILHO, S. C. Suplementação de bovinos em pastagens: uma visão sistêmica. In: SIMPÓSIO DE PRODUÇÃO DE GADO DE CORTE, 4., 2004, Viçosa, MG. Anais... Viçosa, MG: UFV, 2004. p. 93-144.

PEREIRA, O. G.; ROVETTA, R.; RIBEIRO, K. G.; SANTOS, M. E. R.; FONSECA, D. M.; CECON, P. R. Características morfogênicas e estruturais do capimtifton 85 sob doses de nitrogênio e alturas de corte. Revista Brasileira de Zootecnia, Viçosa, MG, v. 40, n. 9, p. 1870-1878, 2011. 
PONTES, L. S.; NABINGER, C.; CARVALHO, P. C. F.; TRINDADE, J. K.; MONTARDO, D. P.; SANTOS, R. J. Variáveis morfogênicas e estruturais de azevém anual (Lolium multiflorum Lam.) manejado em diferentes alturas. Revista Brasileira de Zootecnia, Viçosa, MG, v. 32, n. 4, p. 814-820, 2003.

STATISTICAL ANALYSIS SYSTEM INSTITUTE SAS Institute. SAS/STAT 9.2. User's guide. Cary: SAS Institute Inc, 2008.

SILVA, S. C. da; BUENO, A. A. O.; CARNEVALLI, R. A.; UEBELE, M. C.; BUENO, F. O.; HODGSON, J.; MATTHEW, C.; ARNOLD, G. C.; MORAIS, J. P. G. Sward structural characteristics and herbage accumulation of Panicum maximum cv. Mombaça subjected to rotational stocking managements. Scientia Agricola, Piracicaba, v. 66, n. 1, p. 8-19, 2009.

SILVA, S. C. da; NASCIMENTO JÚNIOR, D. Avanços na pesquisa com plantas forrageiras tropicais em pastagens: características morfofisiológicas e manejo do pastejo. Revista Brasileira de Zootecnia, Viçosa, MG, v. 36, p. 121-138, 2007. Suplemento.

SILVA, W. L.; GALZERANO, L.; REIS, R. A.; RUGGIERI, A. C. Structural characteristics and forage mass of Tifton 85 pastures managed under three postgrazing residual leaf areas. Revista Brasileira de Zootecnia, Viçosa, MG, v. 42, n. 4, p. 238-245, 2013.

SOUSA, B. M. L.; NASCIMENTO JÚNIOR, D.; MONTEIRO, H. C. F.; SILVA, S. C. da; VILELA, H. H.; SILVEIRA, M. C. T.; RODRIGUES, C. S.; SBRISSIA, A. F. Dynamics of forage accumulation in Elephant grass subjected to rotational grazing intensities. Revista Brasileira de Zootecnia, Viçosa, MG, v. 42, n. 9, p. 629638, 2013.

WILHELM, W. W.; McMASTER, G. S. Importance of the phyllochron in studyding development and growth in grasses. Crop Science, Madison, v. 35, n. 1, p. 1-3, 1995. 